\title{
POTRZEBY SZKOLENIOWE W ZAKRESIE KOMPETENCJI KLUCZOWYCH OSÓB DOROSŁYCH
}

\section{RAPORT Z BADAŃ}

Aleksander Kobylarek, Luba Jakubowska, Kamil Błaszczyński,

Noémie Govindin, Piera Sciama, Alcidio Jesus, Claudia Amaral, Samuel Yosef, Amelia Fiorillo 


\section{POTRZEBY SZKOLENIOWE}

W ZAKRESIE KOMPETENCJI KLUCZOWYCH OSÓB DOROSŁYCH RAPORT Z BADAŃ 
The publication prepared as a result of The Erasmus+ Strategic Partnership Project in the Field of Adult Education titled Needs of adults education stakeholders ( $\mathrm{N}$ 2019-1-PLo1-KA204-065792) with experts from the consortium organizations: FUNDACA PRO SCIENTIA PUBLCA (Poland), ITAKA TRAINING (Italy), E-SENIORS: INTTATION DES SENIORS AUX NTIC ASSOCATTION (France) and AFN ACA DEMIA ForMaC̄ão Do NORTE (Portugal).

The European Commission's support for the production of this publication does not constitute an endorsement of the contents, which reflect the views only of the authors, and the Commission cannot be held responsible for any use which may be made of the infor-

mation contained therein

AUTHORS:

Aleksander Kobylarek, Luba Jakubowska, Kamil Błaszczyński, Noémie Govindin, Piera Sciama, Alcidi Jesus, Claudia Amaral, Samuel Yosef, Amelia Fiorillo

STATISTICAL EDITORS:

Kamil Blaszzcyński, University of Wroclaw, Poland

REVIEWE

Tijana Milenkovic Jankovic, the uK

TRANSLATION INTO POLISH AND PROOFREADING

Aleksander Kobylarek, Poland

DESIGN AND DTP:

Hanna Włoch, Poland

Foundation Pro Scientia Publica

Ul. Redycka 37, 51-169 Wrodaw

www.proscientiapublica.pl
Wsparcie Komisji Europejskiej dla produkcji tej publikacji nie stanowi poparcia dla treści, które odzwierciedlają jedynie poglądy autorów, a Komisja nie może zostać pociagnieța do odpowiedzialności za jakiekolwiek wykorzystanie informacii w niej zawartych.

Luty 2021

Creative Commons Attribution 4.0 Internationa Authority code: CC_BY_4_0

(c) (i)

ISBN 978-83-953451-5-9

doi: 10.15503/andr.2021.neon.pl

Photo by

CoWomen ; Green Chameleon ; krakenimages

Marten Bjork ; Sarah Dorweiler ; You X Ventu

on Unsplash

$$
\begin{aligned}
& \text { Wprowadzenie } 4 \\
& \text { Wyniki } 10 \\
& \text { Podsumowanie } 24 \\
& \text { Bibliografia } 30 \\
& \text { Aneksy } 34 \\
& \text { Aneks } 36 \\
& \text { Aneks } 1140
\end{aligned}
$$


1. Wprowadzenie 
Projekt Potrzeby szkoleniowe $w$ zakresie kompetencji kluczowych osób dorostych (N² 2019-1-PLo1-KA204-065792) został stworzony, w odpowiedzi na brak narzędzi, które mogłyby mierzyć potrzeby edukacyjne kadry nauczającej osoby dorosłe.

Pomimo energicznego rozwoju andragogiki, wciąż brakuje narzędzi do badań, typowyc dla tego obszaru. Andragogika korzysta z narzędzi, z dziedzin powiązanych, głównie psychologii. To rozwiazzanie, nie jest jednak w pełni satysfakcjonujące. Po pierwsze dlatego, że wiele narządzi funkcjonuje w ograniczonym dostępie. Po drugie, nie ma takic instytucji, które uczylyby o potrzebach edukacyjnych osób dorosłych oraz edukacyjnych potrzebach ich pracodawców.

W odpowiedzi na wskazane powyżej zapotrzebowanie, koordynatorzy projektu, opracowali kwestionariusz, aby zbadać potrzeby edukacyjne. Kwestionariusz został przetłmaczony na języki partnerów projektu i zastosowany do badań, także przez zagranicznych partnerów projektu. Na podstawie analiz zebranych odpowiedzi, zbudowan klasyfikację potrzeb edukacyjnych w edukacji dorosłych, zdefiniowanych przez koordynatorów badania (Aleksander Kobylarek, Luba Jakubowska, Kamil Błaszczyński, Noėmi Govindin, Piera Sciama, Alcidio Jesus, Claudia Amaral, Samuel Yosef, Amelia Fiorillo).

Prezentowany raport, zawiera informacje o potrzebach edukacyjnych oraz ilościową ewaluacje instytucji zatrudniajacych edukatorów osób dorosłych oraz pracowników NGO w krajach partnerów projektu (Polska Francja, Włochy, Portugalia), w innych krajach europejskich i niektórych krajach pozaeuropejskich. W badaniu wzięło udzia 1176 ankietowanych. Istotny jest fakt, że badanie było przeprowadzone w różnych krajach - nie tylko w krajach partnerów realizujących projekt. Stanowi to gwarancję, że uzyskane wyniki, odzwierciedlają sytuację europejskiego sektora edukacji dorostych.

NARZEDZIA DO DIAGNOZOWANIA KOMPETENCJI KLUCZOWYCH

I POTRZEBY ZMIAN W ORGANIZACII

W celu diagnozy zdefiniowanych potrzeb edukacyjnych wykorzystano autorski kwestionariusz Adult Education Needs Inventory, czyli Inwentarz Potrzeb Edukacyjnych Dorostych (AENI). Kwestionariusz ten jest narzędziem przeznaczonym do badań kompetencji kluczowych osób pracujących w sektorze edukacji dorosłych (Council of European Union, 2018).

Model kompetencji wpisuje się w koncepcję całożyciowego uczenia się i nie koncentruje się na funkcji kompensacyjnej procesu edukacyjnego, tylko promuje wgląd edukatorów w samorozwój oraz w świadomy, ktywny w nim udział. AENI został skonstruowany w oparciu o rekomendacje Unii ropejskiej w kwestii kluczowych kompetencji XXI wieku. W oparciu o te rekomendacje zespół badawczy stworzyl, przetestował i ocenit kwestionariusz AENI z wykorzystaniem metod analiz statystycznych.

Rzetelność testu potwierdzono w wyniku interkorelacji. Trafność kwestionariusza zosta-
la potwierdzona na drodze analizy czynnikowej. Ponadto sprawdzono trafność teoretyczną poprzez korelację AENI z Profilem Kompetencji Społecznych (PROKOS) (Martowska, Matczak, 2013), mierzacym poziom takich kompetencji społecznych jak: asertywne, kooperacyjne, towarzyskie, zaradności społecznej i społecznikowskie. W celu sprawdzenia trafności teoretycznej sformułowano hipotezy, które dotyczyły zarówno korelacji wyników ogólnych (kwestionariuszy AEN PROKOS), jak i wybranych skal. Badania korelacyjne (w którym wzięło udział 98 osób badanych) potwierdzily trafność teoretyczną kwestionariusza AENI.

Przed wykonaniem badań końcowych zostały przeprowadzone także analizy ws taty przeprowad czynnikiem testu rzetelności Alpha-Cronbacha. Wzięło w nich udział 210 uczestników. Wykazana została bardzo wysoka rzetelność stworzonego narzędzia (Cronbach a = 0,846) i jego wymiarów.

AENI dostarczył dwóch głównych informacji: ogólnego wyniku indywidualnego oraz wyników w sześciu subkategoriach diagnostycznych:

1) Kompetencje komunikacyjne (KK); Wielojezzyczność i wielokulturowość (WJiWK);
3) Kompetencje cyfrowe (кс)

4) Kompetencje w zakresie przedsiębiorczości (KP);

5) Otwartość na naukę i kulturę (ONiK);

6) Kompetencje społeczne i obywatelskie (KSiO).

Wszystkie subkategorie zostały opracowane przez polski zespół badawczy (Kobylarek, Jakubowska, Błaszczyński 2020 - artykuł jest zgłoszony do druku), sędziów kompetentnych oraz przy użyciu narzędzi statystycznych, takich jak: 1) analiza czynnikowa; 2) wskaźnik rzetelności Alfa Cronbacha; 3) współczynnik zgodności W-Kendalla.

Każdy mógł osiągnąć maksymalne wyniki wynoszace $100 \%$ z testu ogólnego i w każdej $\mathrm{z}$ subkategorii.

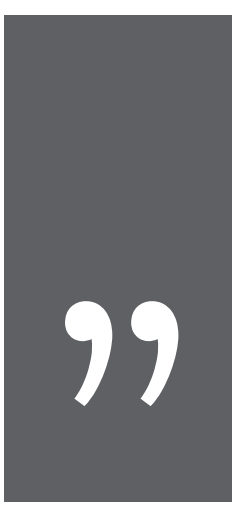

Sugerowana jest następująca klasyfikacja wyników:

20-44\% - niski wynik - silnie odczuwane potrzeby edukacyjne;

45-75\% - średni wynik - przeciętnie odczuwane potrzeby edukacyjne;

76-100\% - wysoki wynik - słabo odczuwane potrzeby edukacyjne.
Druga część badania wiązała się z identyfikacją zgłaszanych przez pracowników potrzeb zmian w organizacji. Pozycje skomponowano z 18 twierdzeń reprezentujacych 18 kategorii (Tabela 1), w których poproszono respondentów o ujawnienie opinii na 5-punktowej skali, rozciągającej się w przedziale od „zdecydowanie się nie zgadzam” do „zdecydowanie się zgadzam”.
Pozycje zawarte $\mathrm{w}$ ankiecie przygotowano na podstawie Dwuczynnikowej Teorii Motywacji Herzberga (źródło: Bassett-Jones, Lloyd, 2005).

Wyniki zaprezentowano procentowo. Im wyższy wynik indywidualny uzyskał badany, tym lepszą miał opinię o organizacji i dostrzegał mniejszą konieczność jej zmiany. 
Tabela 1. Elementy oceny organizacji - lista i opis

\begin{tabular}{|c|c|}
\hline Uznanie przez pracodawcę & Pracownik czuje się doceniony przez pracodawcę. \\
\hline Uznanie przez lidera & $\begin{array}{l}\text { Pracownik czuje się doceniony przez bezpośredniego lide- } \\
\text { ra lub kierownika. }\end{array}$ \\
\hline Osiągnięcie celów organizacji & $\begin{array}{l}\text { Pracownik może osiągnąć cele wyznaczone przez praco- } \\
\text { dawcę. }\end{array}$ \\
\hline Osiągnięcie osobistego sukcesu & $\begin{array}{l}\text { Pracownik ma szanse na osiągnięcie osobistych sukcesów } \\
\text { w organizacji. }\end{array}$ \\
\hline Odpowiedzialność & $\begin{array}{l}\text { Pracownik odczuwa dużą odpowiedzialność za wykony- } \\
\text { wane przez siebie zadania. }\end{array}$ \\
\hline Niezależność & $\begin{array}{l}\text { Pracownik ma szeroką swobodę w realizacji zleconego } \\
\text { zadania. }\end{array}$ \\
\hline Postęp & Pracodawca zapewnia pracownikowi możliwość awansu. \\
\hline Rozwój osobisty & $\begin{array}{l}\text { Obecna praca ma silnie pozytywny wpływ na rozwój oso- } \\
\text { bisty pracowników. }\end{array}$ \\
\hline Rozwój strategii organizacji & $\begin{array}{l}\text { Organizacja pracownika ma jasną strategię rozwoju i pra- } \\
\text { cownik ją rozumie. }\end{array}$ \\
\hline Rozwój ciągłości organizacji & $\begin{array}{l}\text { Organizacja nie ustaje w próbach dalszego doskonalenia } \\
\text { i nieustannie dokłada starań, aby usprawniać i poszerzać } \\
\text { swoją działalność. }\end{array}$ \\
\hline Miejsce pracy & $\begin{array}{l}\text { Organizacja zapewnia pracownikowi odpowiednie miejsce } \\
\text { pracy do zleconych zadań. }\end{array}$ \\
\hline Komfort pracy w organizacji & Organizacja kladzie nacisk na komfort pracy pracowników. \\
\hline Wynagrodzenie & $\begin{array}{l}\text { Pracownik jest zadowolony ze swojego wynagrodzenia } \\
\text { w organizacji. }\end{array}$ \\
\hline Korzyści i bonusy & $\begin{array}{l}\text { Organizacja zapewnia pracownikowi bogatą ofertę świad- } \\
\text { czeń uzupełniających i premii. }\end{array}$ \\
\hline Relacje z szefem & Pracownik ma dobre relacje osobiste ze swoim pracodawcą. \\
\hline $\begin{array}{l}\text { Relacje z kolegami z organi- } \\
\text { zacji }\end{array}$ & Pracownik ma dobre relacje osobiste $\mathrm{z}$ kolegami w pracy. \\
\hline Bezpieczeństwo zatrudnienia & $\begin{array}{l}\text { Organizacja jest stabilna finansowo i daje pracownikowi } \\
\text { poczucie stabilności zatrudnienia. }\end{array}$ \\
\hline Praca i życie prywatne & $\begin{array}{l}\text { Zadania realizowane w organizacji negatywnie wpływają } \\
\text { na życie prywatne pracownika. }\end{array}$ \\
\hline
\end{tabular}

(opracowanie własne na podstawie: Herzberg, Mausner, Snyderman, 1959)
INTERPRETACJA WYNIKÓW

BADANIA POTRZEBY ZMIAN

W ORGANIZACJI

Punktacja została wyrażona procentowo Każde zdanie posiada minimalną wartość o\% a maksimum $100 \%$. Im wyższy wynik uzyska dana osoba, tym lepsza jest jej opinia o danym wymiarze funkcjonowania instytucji. Jedyny wyjątek stanowi ostatnia kategoria skoncentrowana na życiu prywatnym /osobistym. W tym obszarze niski wywiski wy nik świadczy o odpowiednio niskim wplywie życia zawodowego na prywatne.

Zaleca się interpretację uzyskanych wyników odnośnie oceny organizacji według poniższej skali:

$\mathbf{0 - 2 0} \%$ - bardzo niski - bardzo zła opinia na temat organizacji/pracodawcy;

21-40\% - niski - zła opinia na temat organizacji/pracodawcy;

41-6o\% - średni - neutralne podejście do organizacji/pracodawcy;

61-80\% - wysoki - dobra opinia na temat organizacji/pracodawcy

$\mathbf{8 1 - 1 0 0 \% ~ - ~ b a r d z o ~ - ~ b a r d z o ~ d o b r a ~ o p i n i a ~ n a ~ t e m a t ~ o r g a n i z a c j i / p r a c o d a w c y . ~}$

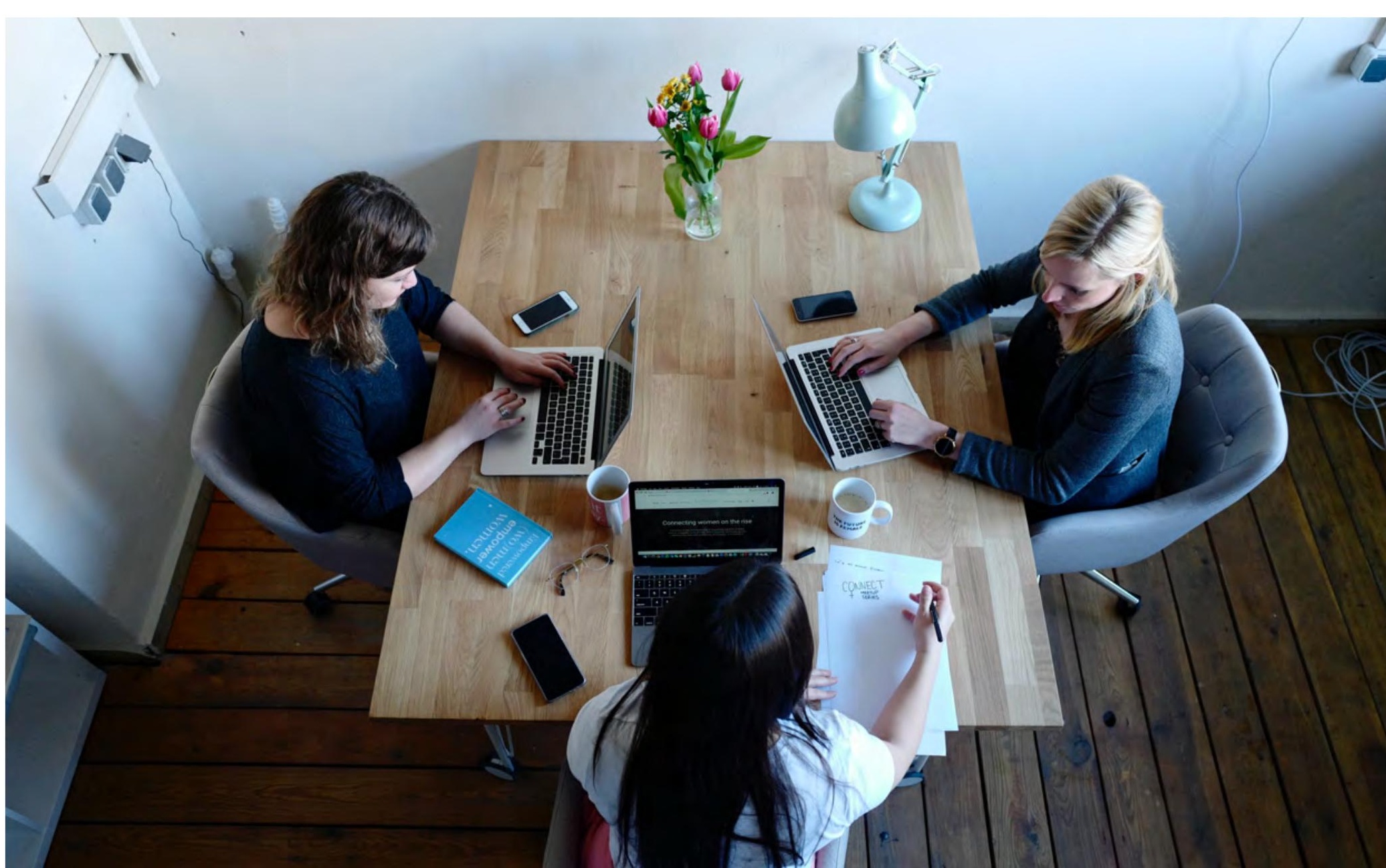


2. Wyniki 
ŚREDNIE WYNIKI DLA

POSZCZEGÓLNYCH KOMPETENCJI

W TEŚCIE AENI

W badaniu wzięlo udział 1176 badanych, którzy uzyskali wynik z testu AENI przeciętnie

na poziomie $78 \%$ i który można sklasyfi-

kować jako dobry. Szczegółowa analiza sub- kategorii AENI ujawniła, że najniższy wynik uzyskano w kompetencjach z zakresu przedsiębiorczości (73\%), który można sklasyfikować jako dobry. Najwyższy wynik odnotowano w zakresie kompetencji cyfrowych $(82 \%)$ oraz kompetencji społecznych i obywatelskich (81\%), które zostały sklasyfikowane jako bardzo dobre.
Wykres 1. Wyniki testu AENI

Średnie wyniki dla podobszarów

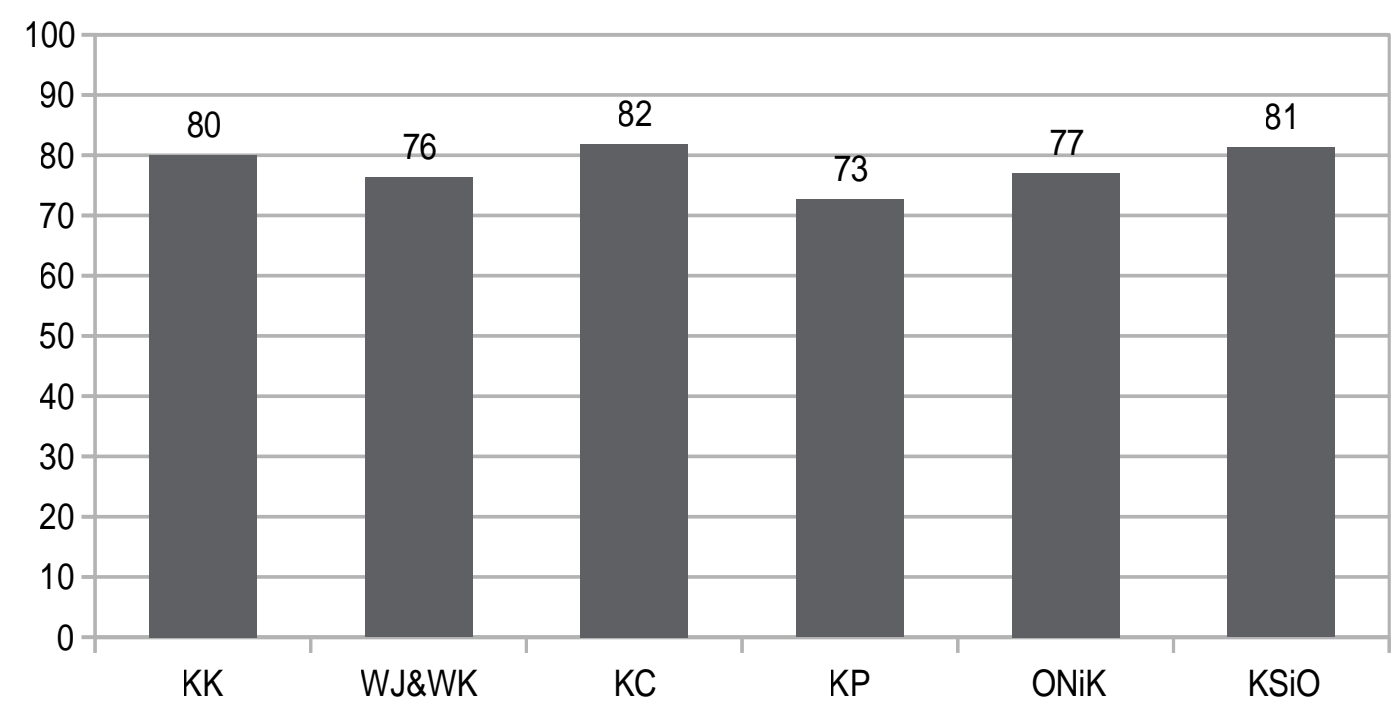

WYNIKI DIAGNOZY POTRZEBY

ZMIAN ORGANIZACJ

Wyniki uzyskane w badaniu ewaluacji organizacji ukazały średni, ogólny w y wynik wynoszący 69\%, który można uznać za wysoki. Analizy poszczególnych podobszarów ukazały najniższy odnotowany wy-

Wykres 2. Wyniki ewaluacji organizacji Średnie wyniki dla podobszarów nik w kategorii praca i życie prywatne. Inne znacząco niskie wyniki uzyskane zostały w kategoriach wynagrodzenie $(51 \%)$ oraz premie i dodatki (42\%). W związku z tym edukatorzy dorostych oraz pracozyści mateialne, które przynosi im wykonywana praca.

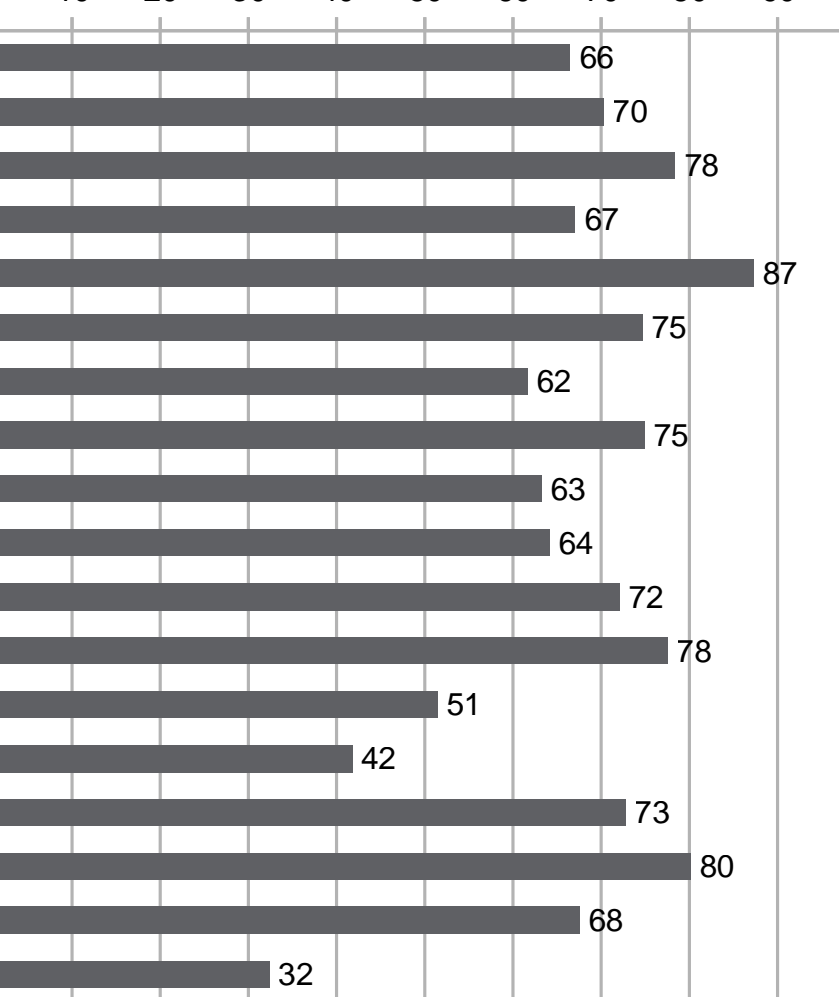


PORÓWNANIE POZIOMU ROZWOJU

KOMPETENCJI KLUCZOWYCH

OBYWATELI Z UE I SPOZA UE

Porównanie średnich wyników dla kompetencji kluczowych obywateli z obszarów UE

spoza UE. W badaniu zostało zarejestrowanych 1049 respondentów Z UE oraz 107 respondentów spoza UE. W badaniu wzięły udział wszystkie kraje unijne z wyjątkiem były Turcja, Wielka Brytania i Ukraina.

Wykres 3. Wyniki testu AENI

Porównanie średnich wyników w podobszarach obywateli z obszarów UE i spoza UE

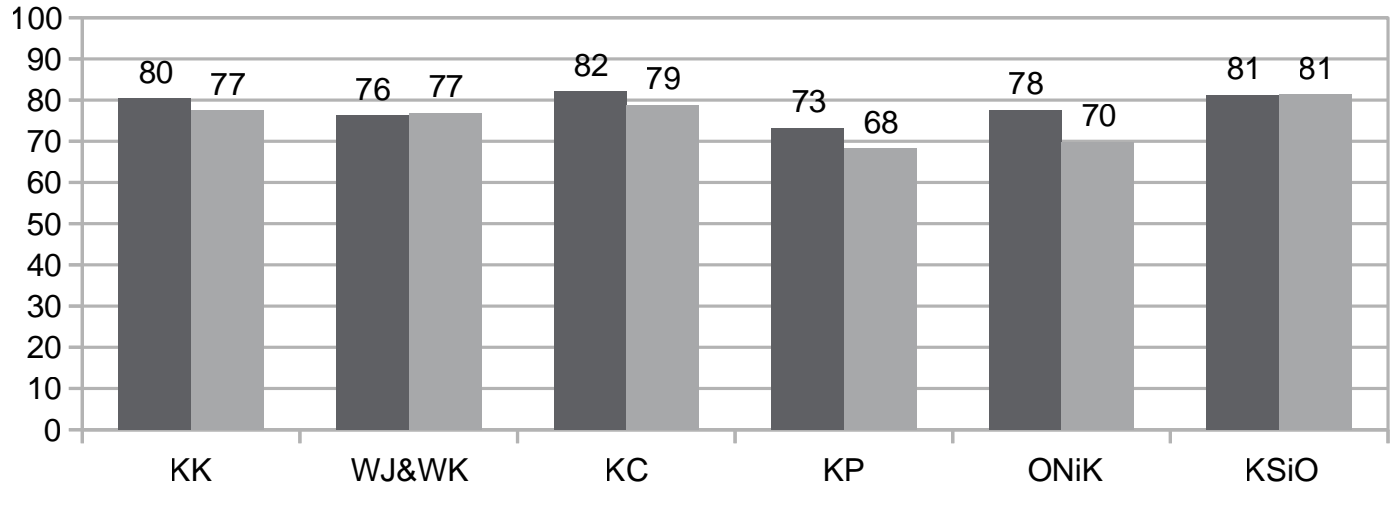

- EU $=$ Non-EU

Ogólny średni wynik z testu AENI dla respondentów z obszaru UE wyniósł $78 \%$, natomiast dla respondentów spoza UE - 75\%. Uzyskane rezultaty pokazują zatem niewielkie zróżnicowanie Sugeruje to, że dorós edukatorzy sek są o wiele bardziej usatysfakcjonowani od pracowników tego sektora spoza UE. Bardzie szczególowa analiza, skupiona na podobszarach testu AENI, ukazała zróżnicowanie w wynikach w zakresie komunikacji, cyfry- zacji, przedsiębiorczości oraz otwartości na naukę. We wszystkich tych kategoriach, najwyższe wyniki otrzymali respondenci z UE. Największe zróżnicowanie wyników, wynoszące $8 \%$, zostato odnotowane w kategoril otwartości na nauke i kulture Można więc założyć, że respondenci z UE są bardziej zadowoleni z poziomu ich kompetencji w zakresie komunikacji, cyfryzacji oraz w szczególności otwartości na naukę i kulture, nižz ich partnerzy z krajów spoza UE.
ZESTAWIENIE OCENY POTRZEB

ZMIAN W ORGANIZACJACH

Z TERENU UE I SPOZA UE

Wykres 4. Wyniki ewaluacji organizacji

Porównanie średnich wyników w podobszarach obywateli z obszarów UE i spoza UE

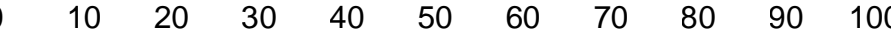

Docenianie przez pracodawce

Docenianie przez lidera

Osiąganie celów dla organizacj

Osiąganie osobistego sukcesu

Odpowiedzialność

Niezależność

Postęp

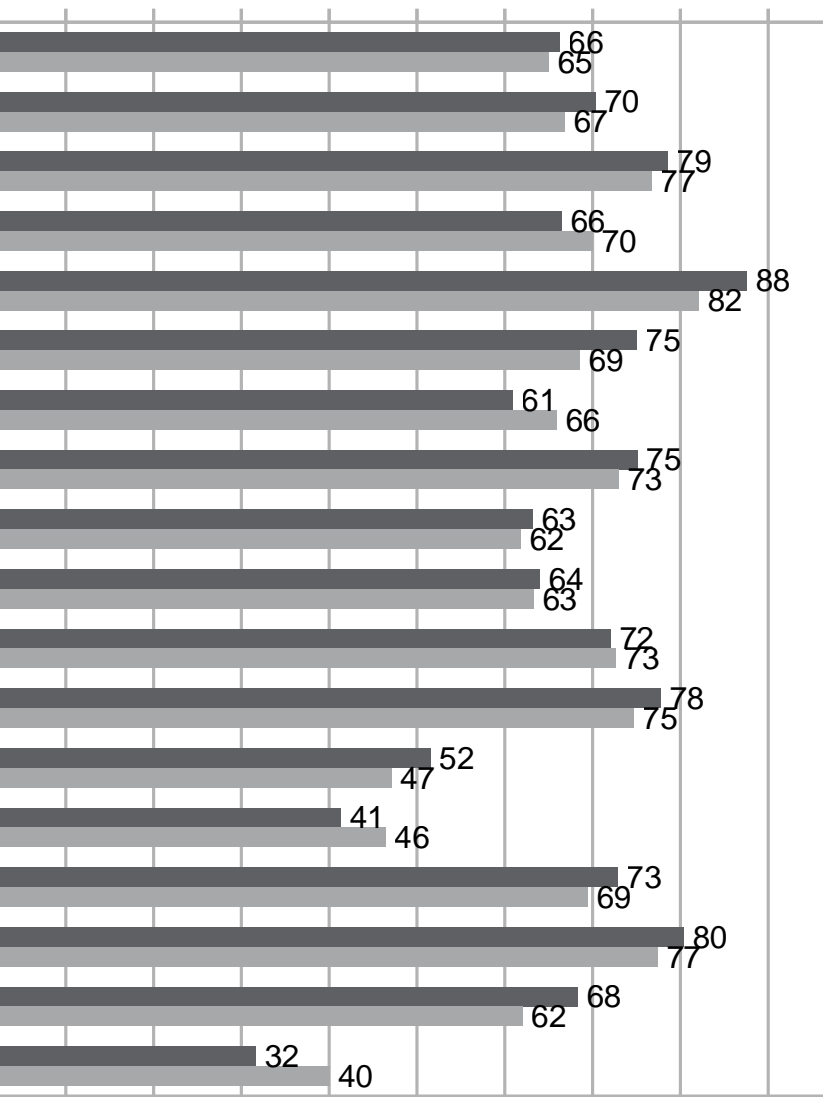

Rozwój osobisty

Strategia rozwojowa organizacj

Spójność rozwojowa organziacj

Stanowisko pracy

Komfort pracy

Wynagrodzenie

Premie i dodatki

Relacje z sze

Relacje z kolegami z organizacj

Stabilność zatrudnienia

Wpływ pracy na życie prywatn

Non-EU $=\mathrm{EU}$

Ocena uzyskanego wyniku badania, wykazała, że ogólne średnie wyniki dla porównywanych grup respondentów wyniosły $69 \%$ wśród badanych pochodzących z UE oraz $67 \%$ wśród badanych spoza UE. A zatem europejscy respondenci oceniają nieco bardziej pozytywnie swoją organizację, niż respondenci spoza UE Szczegółowa analiza (wykres 4) poszczegól ukazała bardziej lub mniej widoczne zróż nicowanie w wynikach we wszystkich badanych kategoriach. Najbardziej widoczne różnice odnotowano w podobszarze dotyczącym poczucia osiągniętego osobistego sukcesu (4\%), odpowiedzialności (6\%), niezależności (6\%), postępu (5\%), wynagrodzenia (5\%) premii i bonusów (5\%), relacji z szefem (4\%), bezpieczeństwa zatrudnieżycie prywatne (8\%). nia $(6 \%)$ oraz obszaru wplywu pracy na 
Na podstawie zestawionych wyników można wnioskować, że respondenci z UE ocenili swoje organizacje bardziej pozytywnie w kategoriach: odpowiedzialność, niezależność, wynagrodzenie, relacje z szefem, bezpieczeństwo zatrudnienia oraz wpływ pracy na życie prywatne. Z drugiej strony, respondenci pochodzący spoza UE docenil swoje organizacje w obszarach takich jak: osiągnięcie osobistego sukcesu, postęp oraz w świadczenia i premie.

Podsumowując powyższe wyniki, możn stwierdzić, że organizacje z obszaru UE były oceniane jako te, które powierzały swoim

PORÓWNANIE OGÓLNYCH ŚREDNICH WYNIKÓW UZYSKANYCH W KRAJACH PARTNERSKICH PROJEKTU W TEŚCIE KOMPETENCJI KLUCZOWYCH AENI

W badaniu zarejestrowano 201 uczestników z Portugalii, 195 uczestników z Włoch, 135 uczestników z Francji oraz 159 uczestników z Polski. Porównanie średnich wy-

pracownikom więcej odpowiedzialności w wykonywanej pracy, oferujące większą niezależność $\mathrm{w}$ działaniu i podejmowaniu decyzji, wypłacały pracownikom bardziej satysfakcjonujace wynagrodzenia, tworzyly się w nich bardziej przyjazne relacje z kadrą kierowniczą, zapewniały bardziej stabilne formalne zatrudnienie i starały się nie ingerować w życie prywatne pracowników. Organizacje spoza obszaru UE były oceniane jako te które oferowaty swoim pracownitego sukcesu, tworzyły więcej możliwości rozwojowych i proponowały bardziej atrakcyjne premie i dodatki.

ników, odnotowanych w poszczególnych krajach, zostało ukazane na wykresie 5 . Najwyższy wynik został odnotowany we Włoszech (79\%), bardzo podobny, ale nieznacznie niższy, odnotowano we Francji i Portugalii $(78 \%)$. Najniższy wynik natomiast został odnotowany w Polsce $(76 \%$ ). Wszystkie zaobserwowane średnie można sklasyfikować jako bardzo wysokie.

Wykres 5. Wyniki testu AENI

Porównanie średnich wyników krajów partnerskich projektu

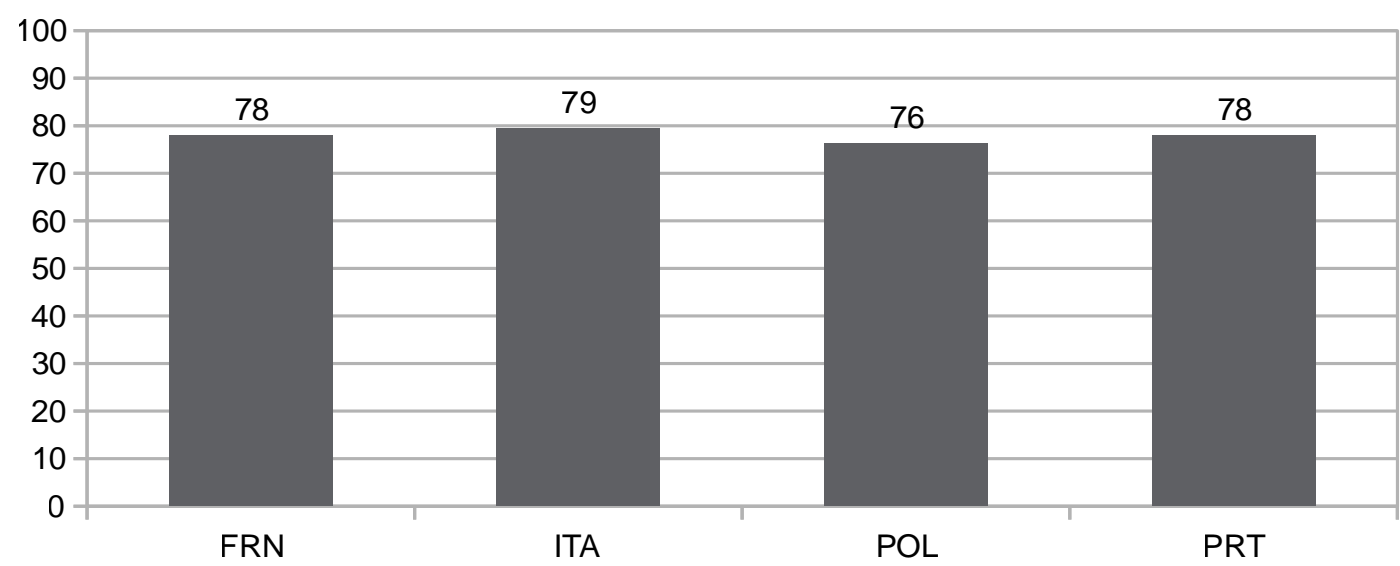

PORÓWNANIE ŚREDNICH WYNIKÓW

UZYSKANYCH W KRAJACH

PARTNERÓW PROJEKTU W TEŚCIE

AENI DLA POSZCZEGÓLNYCH

Wykres 6. Wyniki testu AENI

Porównanie średnich wyników w podobszarach krajów partnerskich projektu

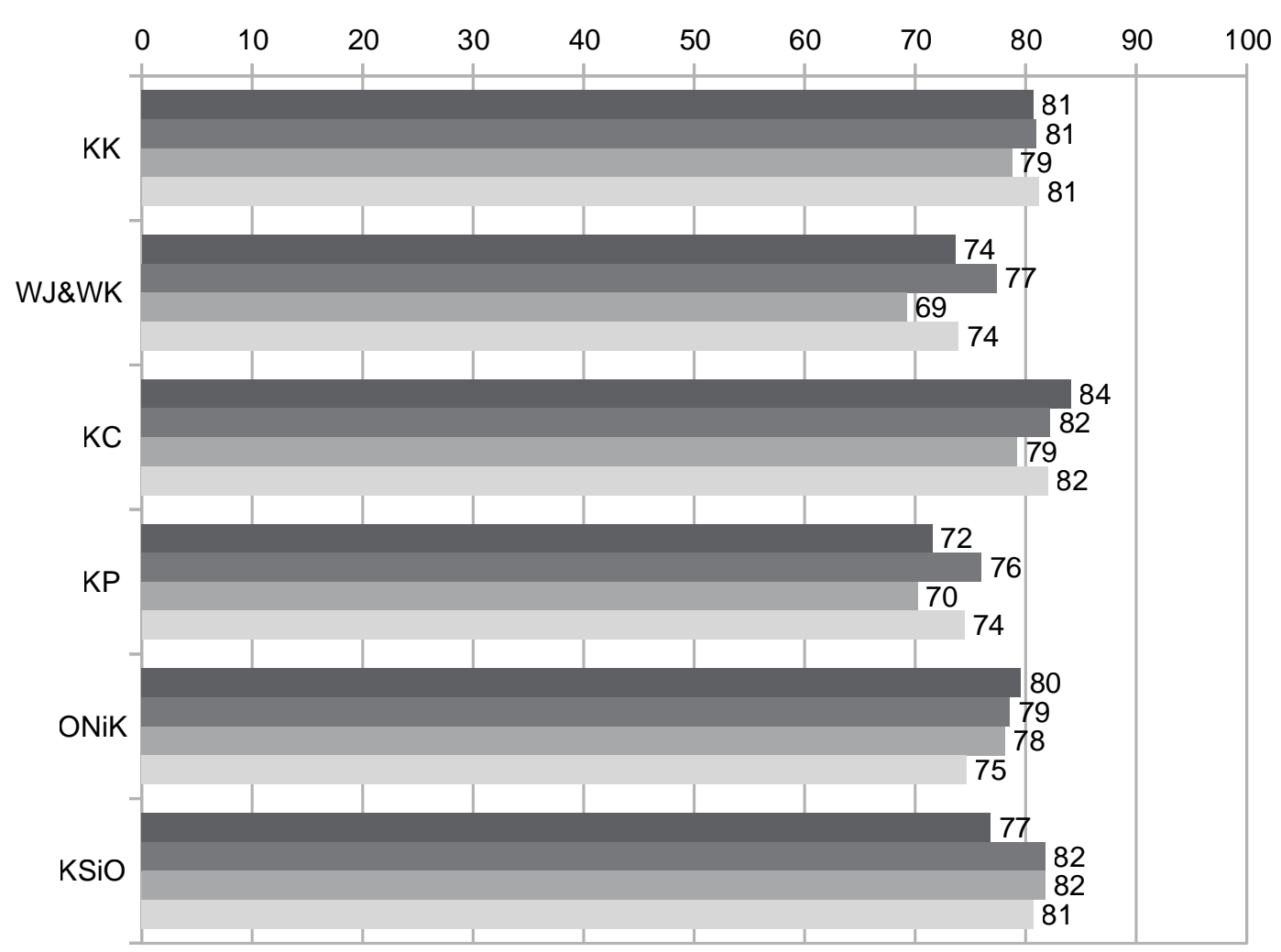

$\varpi \mathrm{PRT} \backsim \mathrm{POL} \backsim \mathrm{ITA} \backsim \mathrm{FRN}$

Po rozdzieleniu ogólnych wyników na poszczególne podkategorie ich analiza ujawnita że największą różnorodność odnotowano w kompetencjach z zakresu wielojęzyczności, wielokulturowości oraz przedsiębiorczości. W obszarze wielojęzyczności i wielokulturowości najwyższy wynik zarejestrowano wśród włoskich uczestników (77\%), natomiast najniższy odnotowano wśród polskich (69\%). Średnie wyniki zarejestrowano we Francji i Portugalii (78\%) jednak byly one blisko wyników, uzyskanych w próbie włoskiej.

Bazując na uzyskanych wynikach, można stwierdzić, że przykład Polski wyróżnia się niższymi wartościami na tle porównywanych 
grup. A zatem polscy edukatorzy dorosłych wykazują potrzeby edukacyjne szczególnie w zakresie doskonalenia kompetencji wielojęzyczności oraz wielokulturowości.

Druga, najbardziej widoczna różnica w wynikach ujawnita się w obszarze przedsiębiorczości, gdzie najwyższy wynik otrzymali Włosi (76\%). Najniższy wynik ponownie - odnotowano w Polsce $(70 \%)$

Niższy wynik, w porównaniu do rezultat

włoskiego, uzyskała także Francja (72\%). Chociaż uzyskane przez Polskę i Francje wyniki, można sklasyfikować jako dobre, wyraźnie pokazują, że wystepują w tych krajach, w niektórych obszarach, potrzeby edukacyjne w zakresie ksztattowania kompetencji przedsiębiorczości, które wymagają poprawy w opinii respondentów. Niższy wynik został uzyskany u respondentów z Portugalii (75\%) także w zakresie kompetencji otwartość na naukę i kulturę.

\section{OCENY POTRZEBY ZMIAN}

W ORGANIZACJACH

Wykres 7. Wyniki ewaluacji organizacji

Porównanie średnich wyników krajów partnerskich projektu

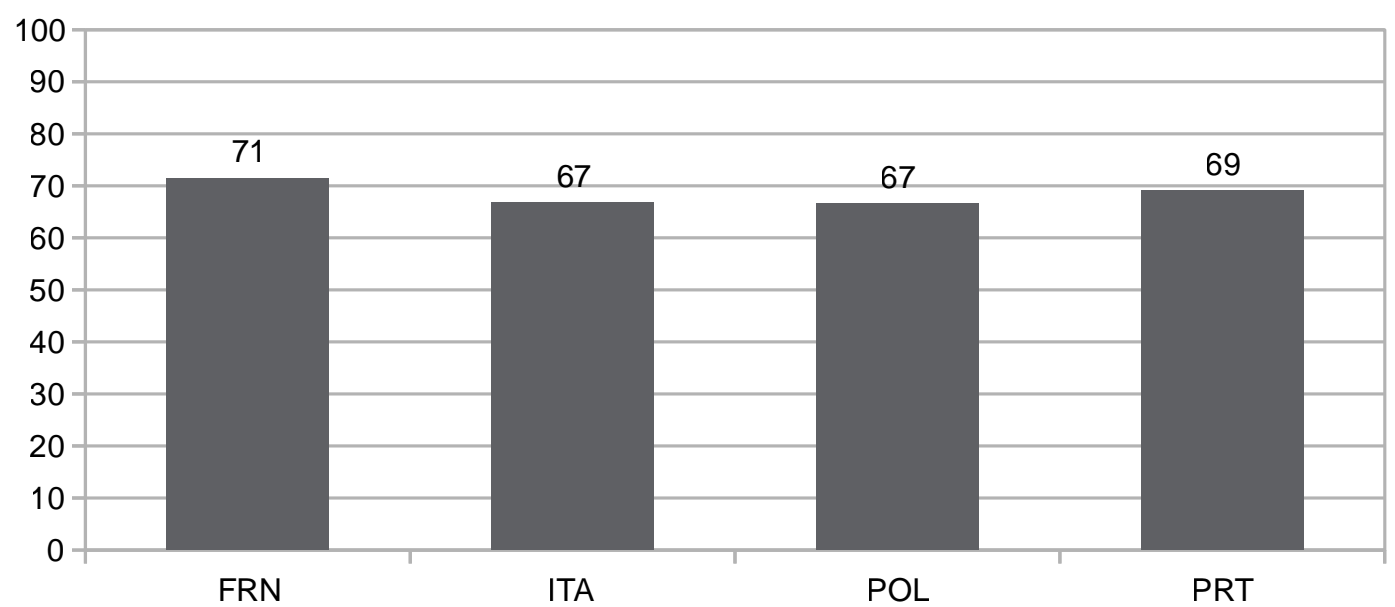

Wyniki dotyczące badania oceny organizacji, ujawnity, że najwyższy średni wynik

co niżej w Portugalii (69\%) i najniżej we Włoszech i w Polsce (67\%). Wszystkie wyniki zostały sklasyfikowane jako dobre.
Wykres 8. Wyniki ewaluacji organizacji

Porównanie średnich wyników w podobszarach krajów partnerskich projektu

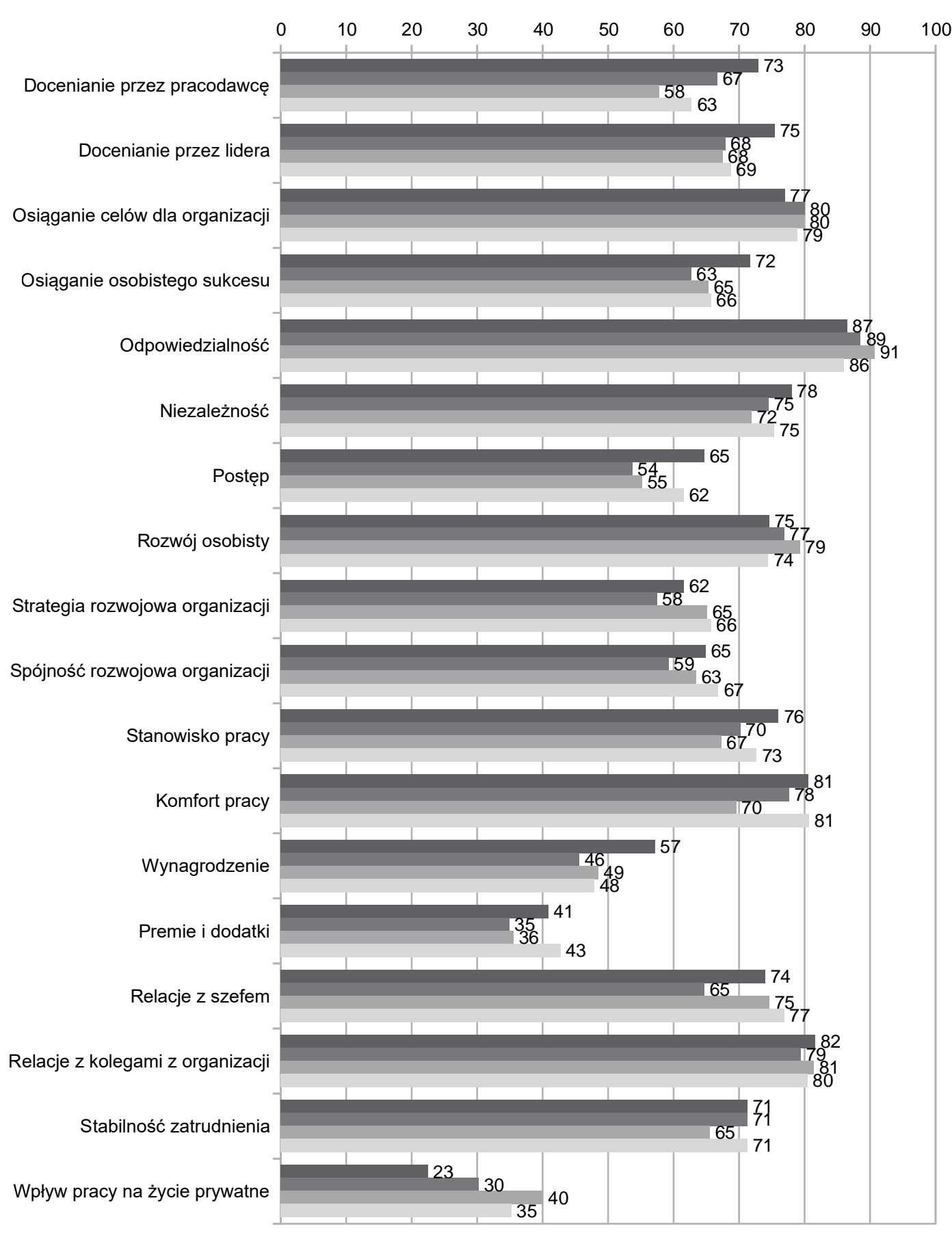

$\square \mathrm{PRT} \backsim \mathrm{POL} \backsim \mathrm{ITA} \backsim \mathrm{FRN}$ 
W podziale na kategorie (Wykres 8), wyniki ukazały duże zróżnicowanie $\mathrm{w}$ wiel obszarach. Największe uznanie pracodawcy odnotowano we Francji (73\%), a najniższe w Polsce (58\%). Najwyższe przez widn, w porównaniu z wszystkim innymi badanymi krajami, zarejestrowan we Francji (75\%). Osiąganie celów w organizacji było najlepiej ocenione we Włoszech i w Polsce (80\%). Największy wskaźnik osiągniętego sukcesu osobistego uzy skała Francja (72\%). Najwieksze poczuci odpowiedzialności odnotowano w polskiej próbie badawczej (91\%). Najwyższy poziom niezależności uzyskano we francuskiej próbie badawczej (78\%). Także we Francji odnotowano najwyższy poziom postępu (65\%). Na największe możliwości rozwoju osobistego wskazywano w Polsce (79\%) Rozwój strategii organizacji był na tym samym poziomie oceny w Polsce $(65 \%)$ i Portugalii (66\%). Spójność rozwojowa

PROFIL INSTYTUCJI ORGANIZUJĄCYCH EDUKACJE DOROSŁYCH

\section{W POSZCZEGÓLNYCH KRAJACH}

Na podstawie uzyskanych danych, można wyprowadzić wstępne wnioski, co do typu instytucji zajmujących się edukacją dorosłych w krajach partnerów projektu.

W Polsce badani mniej więcej w równym stopniu identyfikowali różne typy organizacji 39 prywatnych, 32 panstwowych i 33 pozarządowych).

We Francji i Włoszech organizacja edukacj dorosłych była identyfikowana przede wszystkim z sektorem prywatnych. We Francji ba- organizacji była najlepiej oceniana w Portugalii (67\%). Atrakcyjność stanowiska pracy została najwyżej oceniona we Francj (76\%). Poziom komfortu pracy był tak samo określany we Francji jak i Portugalii (81\%). Najwyższe zadowolenie $\mathrm{z}$ wynagrodzenia odnotowano we Francji (57\%) wynik można określić jako niski. Oceny wysokości premii i dodatków mogą zostać sklasyfikowane jako niskie we wszystkich krajach (35\% do 43\%). Relacje z szefem najlepiej były oceniane wśród badanych pracowników z Portugalii (77\%). Relacje z kolegami zostały ocenione podobnie we wszystkich krajach i wynosity od 79\% do $82 \%$. Zaskakująco, bezpieczeństwo zatrudnienia jest tak samo oceniane we Francji, Włoszech i niższym rezultatenn w Polsce (65\%). Najwyższy wpływ pracy na życie prywatne został zadeklarowany w Polsce (40\%), najniżej natomiast we Francji (23\%).

dani zidentyfikowali 98 prywatnych, 39 państwowych i 36 pozarządowych organizacji, z kolei we Włoszech 51 prywatnych, 44 państwowych i 38 pozarządowych.

W Portugalii odnotowano dysproporcja między liczba organizacji prywatnych (54) i pozarządowych (50) a państwowymi (32).

Z tego zestawienia wynika, że sektor pozarządowy edukacji dorosłych był najmniej reprezentowany (Portugalia stanowita tu wyjątek), a najwyżej reprezentowany by sektor prywatny, przy czym największe dysproporcje między liczbą ocenianych organizacji występowały we Francji, a najmniejsze w Polsce.
Wykres 9. Ewaluacja organizacji

Porównanie wyników w perspektywie typu organizacji

30

Docenianie przez pracodawce

Docenianie przez lidera

Osiąganie celów dla organizac

Osiąganie osobistego sukces

Odpowiedzialność

Niezależność

Rozwój osobisty

Strategia rozwojowa organizaci

Spójność rozwojowa organizaci

Stanowisko pracy

Komfort pracy

Wynagrodzeni

Premie i dodatki

Relacje z szefem

Relacje z kolegami z organizac

Stabilność zatrduenieni

Wpływ pracy na życie prywatne

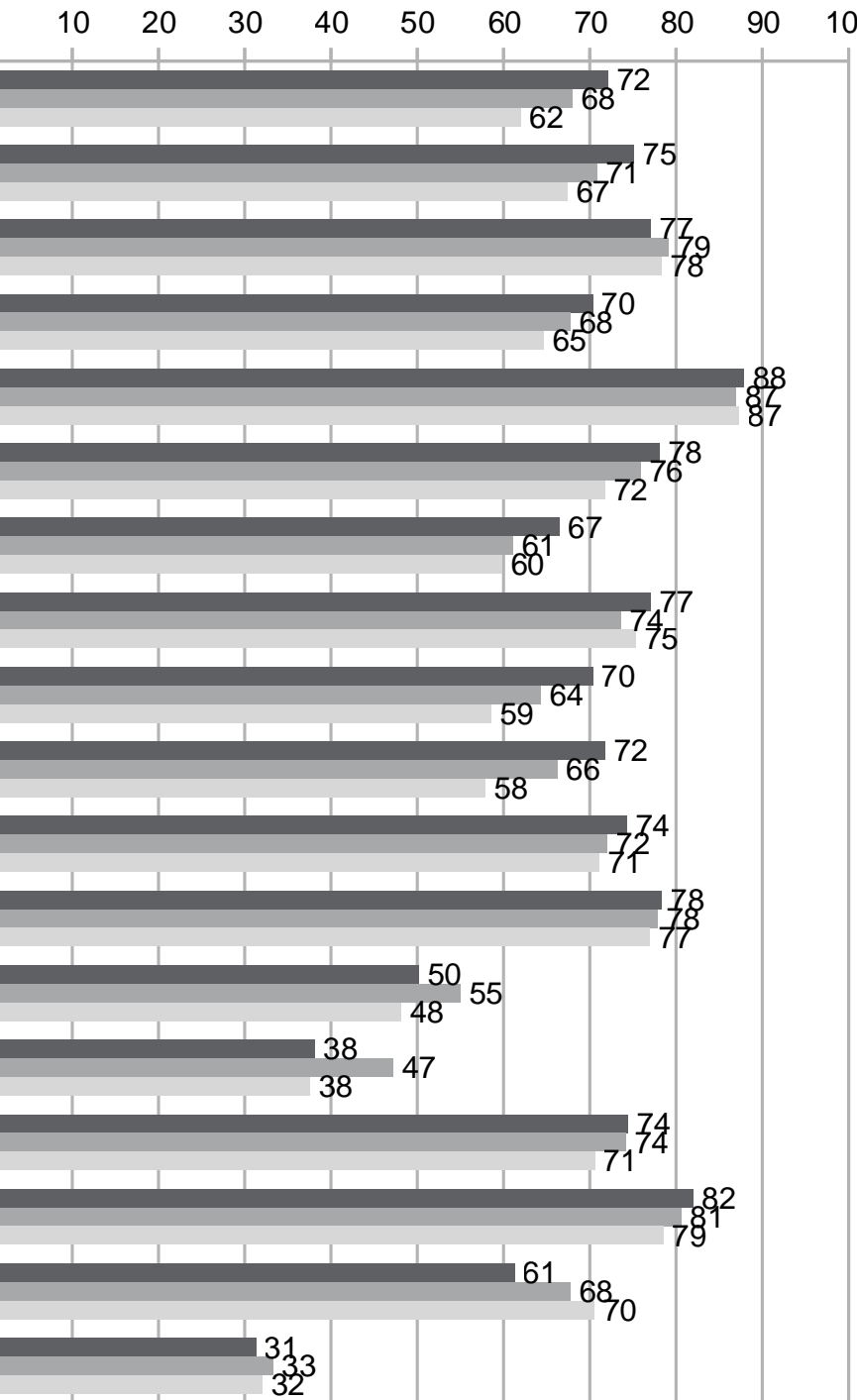

Państwowa Prywatna NGO 
OCENA POSZCZEGÓLNYCH TYPÓW

ORGANIZACJI

Wykres 10. Typy organizacji poddane ocenie respondentów

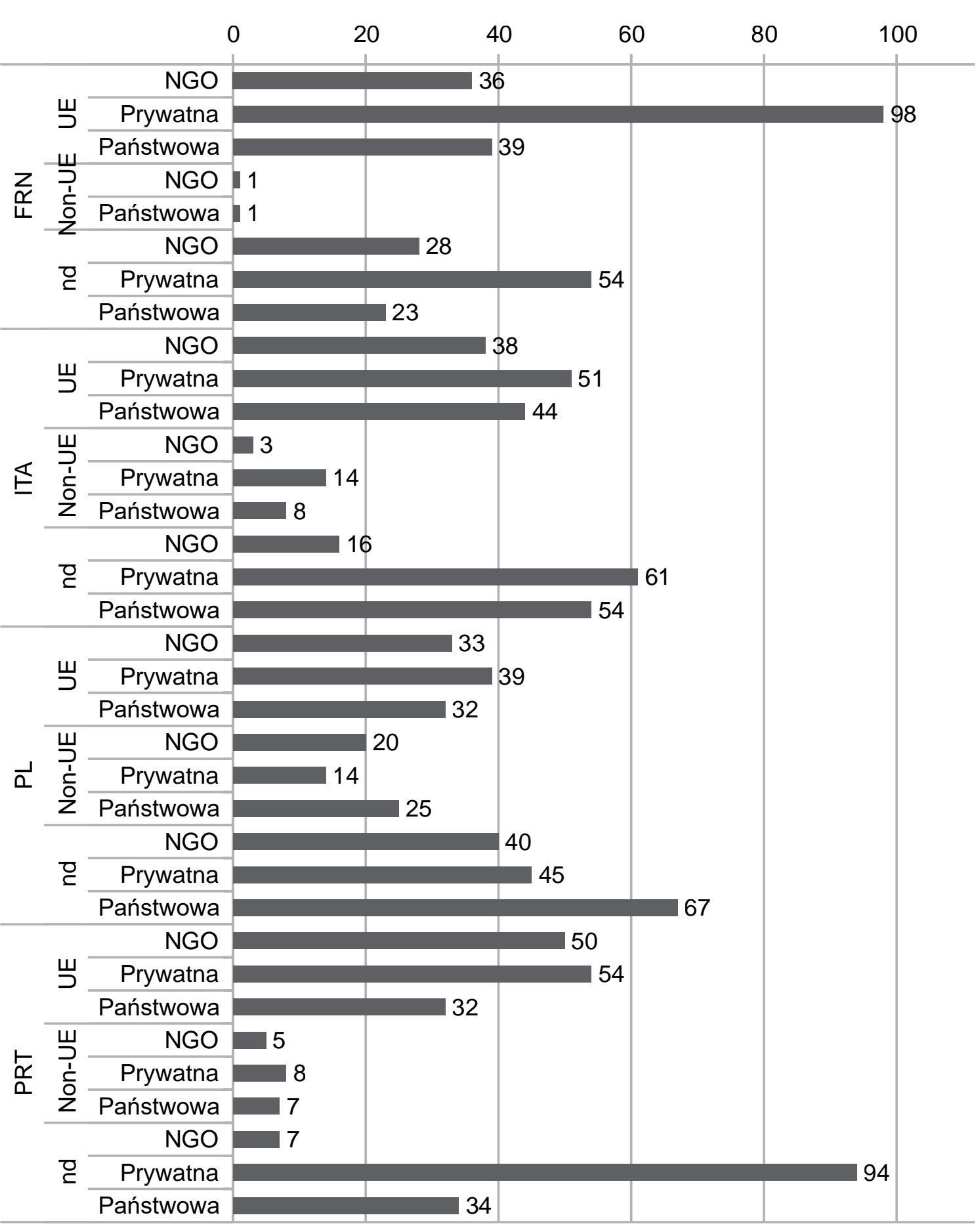

Zestawienie ewaluacji poszczególnych typów organizacji pod wzgledem potrzeb zmian pokazuje, iż w większości przypadków to właśnie organizacje pozarządowe są lepiej oceniane na tle pozostałych typów organizacji. Na największe potrzeby zmian w działalności organizacji respondenci wskazują w przypadku instytucji państwowych. Prawidłowości te są inne w przypadku ws- kaźników związanych z czynnikami stricte ekonomicznymi. Organizacje pozarządowe są najgorzej oceniane $\mathrm{w}$ przypadku poziomu zarobków, premii i stabilności zatrudnienia. Wskazuje to na większe potrzeby zmian $\mathrm{w}$ tym zakresie $\mathrm{w}$ organizacjach pozarzaadowych, np w postaci dofiania i zwięszenia stabilności zatrudnienia. 
3. Podsumowanie

\section{PODSUMOWANIE}

we 
Projekt miał na celu diagnozę potrzeb edukacyjnych edukatorów dorosłych i pracowników NGO oraz ocenę konieczności zmian w ich organizacjach. Pomiary stanowity podstawę do trzech typów analiz: 1) ogólnych wyników uzyskanych przez respondentów; 2) ogólnych wyników uzyskanych przez obywateli UE oraz obywateli spoza UE; 3) ogólnych wyników uzyskanych przez respondentów reprezentujących mieszkańców krajów partnerów projektu.

Na pierwszym poziomie analizy wykazaty że najmniej odczuwane są potrzeby edukacyjne związane z ksztaltowaniem kompetencji cyfrowych (82\%), natomiast najbardziej te, które są związane z kompetencjam z obszaru przedsiębiorczości (73\%). Ocena organizacji wykazała, że uczestnicy byli w wysokim stopniu usatysfakcjonowani z zakresu obowiązków (87\%). Respondenci wykazywali najmniejsze zadowolenie z wysokości otrzymywanych premii i dodatków ( $42 \%$ ), a także z wysokości wynagrodzenia (51\%).

Na drugim poziomie analiz - skupiono się na porównaniu obywateli krajów UE i spoza UE Okazało się, że w przypadku większości potrzeb edukacyjnych, poziom satysfakcji/zaspokojenia wśród uczestników z krajów UE by większy niż respondentów spoza UE. Jedyny wyjątek odnotowano w przypadku kompetencji związanych z wielojęzycznością i wielokulturowością, które okazały się przeważa $(+1 \%)$ na korzyść krajów spoza UE. Ocen organizacji, wskazywana przez większość wyników, ukazała wyższe uznanie dla organizacji z UE, z godnym uwagi wyjątkiem w osiągnięciu osobistego sukcesu $(+4 \%)$ oraz kwestii premii i dodatków (+6\%) z przewaga organizacji spoza krajów UE.

$\mathrm{Na}$ trzecim poziomie analiz - skupienie się na uczestnikach reprezentujących partnerów zamieszkujących kraje projektu wykazało, że potrzeby edukacyjne są najlepiej zaspakajane we Francji (71\%). Znacznie niższe wyniki, zostały odnotowane we Wloszech i Polsce (67\%). Analiza poszczególnych kompetencji ujawnita, że:

- we Francji największe potrzeby edukacyjne związane są z przedsiębiorczością

- we Włoszech iw Polsce największe potrzeby edukacyjne związane są z rozwojem kompetencji z zakresu wielojęzyczności i wielokulturowości oraz przedsiębiorczości;

- w Portugalii najwieksze potrzeby edukacyjne zwązane za z kenetencjami z zakresu wielojęzyczności wielokulturowości, przedsiębiorczości oraz otwartości na naukę i kulturę.

Poziom zróżnicowania wyników odnotowany w ocenie obszarów organizacji byl duży, że przy uwzględnieniu tylko znaczących ocen, ujawnity się znaczące dysproporcje w następujących obszarach:

1) docenienie przez pracodawce, 2) docenienie przez lidera,

3) osiąganie osobistego sukcesu, 4) postęp,

5) strategia rozwojowa organizacji, 6) rozwój stabilności organizacji,

7) warunki w miejscu pracy,

8) komfort pracy,

9) wysokość wynagrodzenia,

10) premie i dodatki,

11) relacje z szefem,

12) bezpieczeństwo zatrudnienia oraz

13) wpływ pracy na życie prywatne.

Analiza wyników pokazała, że ogólny poziom zaspokojenia potrzeb edukacyjnych nauczyzaspokojenia potrzeb edukacyjnych nauczycieli uczniów dorosłych oraz rozwój organi-
zacji są satysfakcjonujące. Jednak wciąż istnieją obszary wymagające poprawy, przede wszystkim w zakresie kompetencji wielojęzyczności i wielokulturowości oraz przedsiębiorczó́ci. Wszystkie przyszle projekty, majace na celu jące na celu poprawę potrzeb nauczycieli uczniów dorosłych powinny skupić się właśnie na tych kompetencjach. Największe niedostatki organizacji zatrudniających edukatorów dorosłych oraz pracowników sektora edukacji dorosłych sa zlokalizowane w obszarze wynagrodzeń i finansów, które zostały zdiagnozowane na krytycznym poziomie i są istotn składową materialnego poczucia bezpieczeństwa oraz mogą być ważnym czynnikiem w przyciaganiu kompetentnych osób do tego typu działalności.

Obywatele z krajów UE mają generalnie zaspokojone potrzeby edukacyjne w większym stopniu w porównaniu z obywatelami

spoza UE i także oni oceniają swoje organizacje lepiej. Jednak wykazują niższy poziom osiagania osobistego sukcesu, co sugeruje, że edukatorzy osób dorosłych i pracownicy NGO z krajów UE, nie łączą swojej aktywności zbyt mocno z osobistym sukcesem, co $\mathrm{z}$ kolei może mieć przesłanki kulturowe lub ekonomiczne.

Wreszcie, jeśli weźmiemy pod uwagę tylko uczestników reprezentujących kraje zaaniżowane w projekt, gažowane w projekt, istniją znaczące przestanki co do konieczności wsparcia zmian w wymienionych niżej obszarach:

docenienia przez pracodawce, szczególnie dotyczy to Polski;

docenienia przez lidera, dotyczy oprócz Françi wszystkich badanych krajów

च osiągania osobistego sukcesu, zwłaszcza jeśli chodzi o Włochy;

च osiągania postępu, szczególnie we Włoszech i w Polsce;

च rozwoju strategii organizacji, w szczególności we Włoszech;

च rozwoju stabilności organizacji, w szczególności we Włoszech;

warunków pracy, dotyczy to szczególnie Polski;

घ komfortu pracy w organizacji, dotyczy to szczególnie Polski;

च wysokości wynagrodzenia, dotyczy wszystkich badanych krajów;

च dodatków i premii, które są oceniane jako na niskim poziomie we wszystkich badanych krajach;

relacii z szefem, zwłaszcza we Włoszech;

च bezpieczeństwa zatrudnienia, szczególnie w Polsce;

『 wpływu pracy na życie prywatne, szczególnie w Polsce. 
Raport został oceniony przez niezależną recenzentkę Tijanę Milenkovic Jankovic (UK), która pracowała w różnorodnych, międzynarodowych projektach z sektora edukacji dorostych, przez ponad 20 lat. Doświadczenie zawodowe dało jej możliwość zdobycia wglądu i zrozumienia funkcjonowania organizacji i instytucji edukacyjnych w różnych

sektorach oraz we wszystkich fazach cyklu edukacyjnego. Doświadczenie w obszarze ewaluacji zdobywała jako niezależny konsultant w ramach Projektu Ewaluacja UNHCR Program Szkolen Zawodowych w Serbii oraz jako Lux-Development regionalny freelancer i krajowy konsultant w Czarnogórze.

\section{Główne konkluzje Tijany Milenkovic Jankovic, dotyczące projektu:}

1. AENI zapewnia solidny, ogólny wgląd w potrzeby edukacyjne osób dorostych. Nawet jeśl generalne wyniki testu AENI, pokazują gtównie wysokie wyniki we wszystkich krajach partnerskich, opinie opierają się na samoocenie. Otrzymane wyniki, mogą być wskazów$k a$, dla interesariuszy w państwach partnerskich co do najbardziej potrzebnych kompetencji edukatorów osób dorostych, które moga stużyć do planowania oraz wskazówek, jak je poprawic w poczatkowej fozie procesu edukacji, jak również w kursach Continuous Professional Development (CDP) dla edukatorów osób dorostych, ale także dla wsparcia procesu walidacji kompetencji, nabytych $w$ róż nych konteks

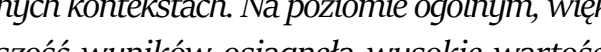

Jednak szczególną potrzebę zidentyfikowano w obszarze kompetencji wielojęzyczności i wielokulturowości (WJiWK) oraz kompetencji w zakresie przedsiębiorczości (KP).[...]

2. Istotne bytoby, aby organizacje, zaangażowane $w$ badanie, otrzymaty jego wyniki i miaty szansę na porównanie rezultatów $z$ ogólnymi wynikami na poziomie ich kraju jak również wynikami z innych panistw. Może to postuży eflensjin zichws dziatań, mających na celu poprawę sytuacji w organizacji. [...]

3. Narzędzie badań ilościowych w zakresie oceny organizacii, tworzy możliwość przygotowania bardziej wnikliwych badań jakościowych. 
4. Bibliografia

\section{BIBLIOGRAFIA}

whe 
Bacigalupo, M., Kampylis, P., Punie, Y., \& Van den Brande, G. (2016). EntreComp: The entrepreneurship competence framework. Luxembourg: Publication Office of the European Union, 10, 593884

Bassett-Jones, N., \& Lloyd, G. C. (2005),Does Herzberg's motivation theory have stayin power? Journal of Management Development, Vol. 24 Iss 10 pp. 929-943, http://dx doi.org/10.1108/02621710510627064.

Buiskool, B. J., Broek, S. D., van Lakerveld, J.A Zarifis, G. K., \& Osborne, M. (2010). Key competences for adult learning professionals. Contribution to the development of a reference framework of key competences for adult learning professionals, 157

Burns, D. (1985). Intimate connections. New York: Signet (Penguin Books).

Caena, F. (2013). Supporting teacher competence development for better learning outcomes Education \& Training, European Commission, p. 5-59.

Council of Europe. Council for Cultura Co-operation. Education Committee. Modern Languages Division. (2001). Common European Framework of Reference for Languages: learning, teaching, assessment. Cambridge University Press.

Council of the European Union. (2018). COUNCIL RECMMENDATIONS, 22 May 2018, with reference to key competences in the process of life-long learning. (2018/C 189/1). Official Journal of the European Union, pp. 1-13.

Council Resolution on a renewed European agenda for adult learning OJ C 372 20.12.2011, p. 1-6.

EU Science Hub - European Commission. 2020. Entrecomp: The Entrepreneurship
Competence Framework. - EU Science Hub European Commission. [online] Available at: <https://ec.europa.eu/jrc/en/publication/eur-scientific-and-technical-researchreports/entrecomp-entrepreneurship-competence-framework $>$ [Accessed 15 November 2020].

Europa.eu. 2020. Common European Framework of Reference. Europass. [online] Available at: <https://europa.eu/europass/en/ common-european-framework-reference> [Accessed 15 November 2020].

Faure, E., Herrera, F., Kaddoura, A. R., Lopez, H., Petrovski, A. V., Rahnema, M., \& Ward, F. C. (1972). Learning to be: the world of education today and tomorrow. Paris: UNESCO.

Głomb, K. (2020). Edukacja dla Przemystu 4.o. Wyzwania dla Polski [Education for Indus-try 4.0 A Challenge for Po land]. Warszawa: Agencja Rozwoju Przemystu.

Griffith, W. S. (1978). Educational Needs: Definition, Assessment, and Utilization. The School Review, 86(3), pp. 382-394.

Hakio, K., \& Mattelmäki, T. (2019). Future Skills of Design for Sustainability: An Awareness-Based Co-Creation Approach. Sustainability(11), pp. 1-24.

Herzberg, F., Mausner, B. and Snyderman, B. (1959), The Motivation to Work, Wiley, New York,NY

Hipkins, R. (2018). How the key competencies were developed: The evidence base. Wellington: New Zealand Council for Educational Research.

Kobylarek, A. (2009). Kompetencje komunikacyjne w systemie umiejętności nauczyof teachers' abilities]. In K. Błaszczyk,
M. Drzewowski, \& W. Maliszewski, Komunikacja spoteczna a zarządzanie we wspótczesnej szkole [Social communication and management in a modern school] (pp. 334342). Toruń: Adam Marszałek.

Martowska, K., \& Matczak, A. (2013). Pomiar kompetencji społecznych - prezentacja nowego narzędzia diagnostycznego [Measuring social skills - presentation of a new diagnostis tool]. Psychologia Jakości Życia [Psychology of the Quality of Life] (1) pp. 43-56.

Morris, E. (2001). Special Educational Needs Code of Practice. London: Department for Education and Skills.

Nijssen, A., van Lakerveld, J. A., Buiskool, B. J, den Oudendammer, F., Broek, S. D., \& Hake, B. (2008). ALPINE - Adult Learning Profession in Europe: A Study of the Current Situation, Trends and Issues. Project Report. Research voor Beleid, Zoetermeer, Netherlands.

Padzik, K. (2016). Ocena zintegrowana Assessment i Development Center. Warszawa: Wolters Kluwer.

Paterson, R. (2000). The Assertiveness Workbook: How to Express Your Ideas and Stand Up for Yourself at Work and In Relationships. Oakland: New Harbinger.

Petrètiène, A., Daukšienė, J., \& Grašienė, (2020). Creativity and speciality language in the context of the development of key competences. Mokslas - Lietuvos ateitis(12), pp. 1-7.

Radovan, M. (2019). Cognitive and Metacognitive Aspects of Key Competency "Learning to Learn”. Pedagogika(1), pp. 28-41.

Stufflebeam, D. L., McCormick, C. H., Brinkerhoff, R. O. \& Nelson, C. O. (2012). Conducting Educational Needs Assessments. Springer.
Warzocha, T. (2016). Kompetencje komunikacyjne jako komponent kompetencji spolecznych nauczycieli akademickich - założenia do badań [Communication skills as a component of social skills for tion - Engineering - Information Technologies] (2), pp. 70-75. 


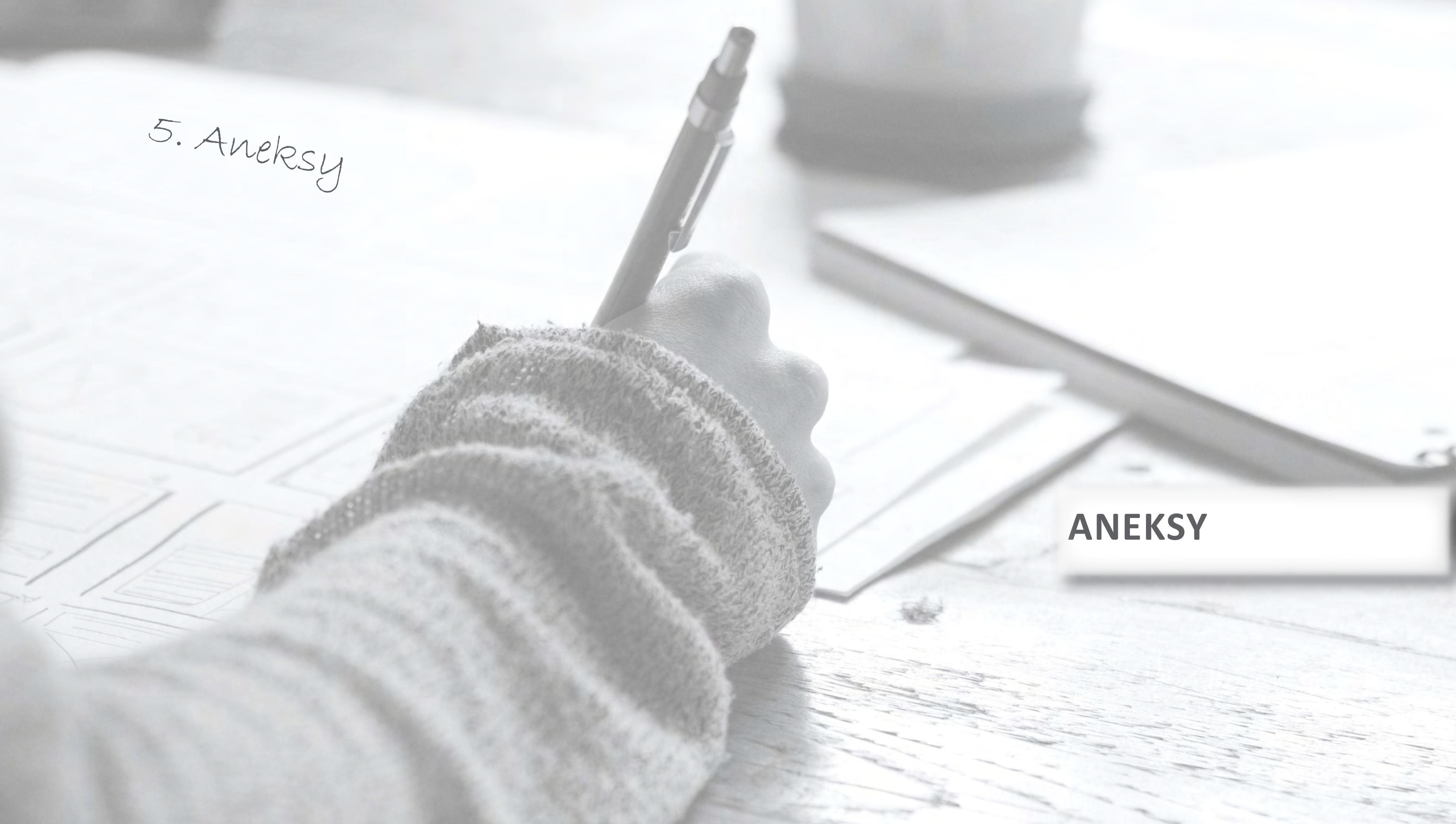


Kwestionariusz do badania potrzeb szkoleniowych $w$ zakresie kompetencji kluczowych osób dorostych

Poniżej znajduje się lista 39 twierdzeń. Oceń proszę na skali od 1 do 5 , a ile zgadzasz sie $\mathrm{z}$ danym twierdzeniem odnoszącym się do Ciebie (1 - zdecydowanie się nie zgadzam,

5 - zdecydowanie się zgadzam). Nie ma odpowiedzi dobrych i złych. Nie poświęcaj

\section{UWAGA: Prosimy o ocenę wszystkich twierdzeń.}

1 = zdecydowanie się nie zgadzam, 5 = zdecydowanie się zgadzam

KK W każdej sytuacji potrafie prowadzić rozmowę

1 (np. w trudnej sytuacji konfliktowej albo gdy rozmówca ma odmienne zdanie)

KK Uważam, że zazwyczaj w rozmowach wysyłam jasne

i zrozumiałe komunikaty

3 KSiO W poszukiwaniu informacji staram się korzystać

z różnych źródeł

KK Bardzo często doświadczam sytuacji, kiedy trudno mi

4R wyrazić myśl

5 KK Zazwyczaj nie mam problemów ze zrozumieniem

rozmówcy

$6 \quad$ KK Lubię dyskutować z różnymi osobami

7 KK Czuję się swobodnie podczas konwersacji z innymi ludźmi

$8 \quad$ KK Potrafię nieszablonowo wyrażać swoje myśli

WJiWK Posługuję się swobodnie w mowie i piśmie więcej

niż jednym językiem obcym

ONiK Myślę, że moja znajomość innych języków obcych nie

musi być dalej rozwijana

11 WJiWK Wykorzystuję różne okazje do uczenia się języków

11 obcych

12 WJiWK Lubię uczyć się nowych języków 


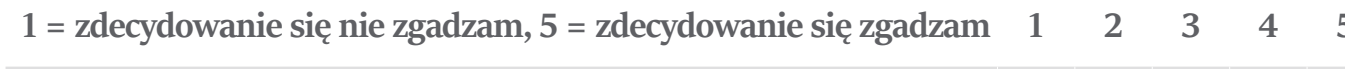

13 WJiWK Na co dzień korzystam z obcego języka (np. oglądam filmy, czytam książi)

14R ONiK Uważam, że matematyka nie pomaga docierać do prawdy

ONiK Istnieją uzasadnione wątpliwości, co do niektórych

15R teorii naukowych np. wpływ czy człowiek wplywa na klima lub jakie jest działanie szczepionek

16 KP Uważam, że skuteczne działanie wymaga jasnego i przejrzystego planu

17R KP Zdarza mi się postępować nielogicznie

18 KSiO Przy planowaniu korzystam często w swoich działaniach z różnych źródeł

19 KP Zazwyczaj działam według wcześniej ustalonego planu

KC Wiem jak wykorzystać nowe technologie do bardziej skutecznego komunikowania się

21 KC Korzystam z różnych nowinek technologicznych

22 KC Czuje, że jestem wystarczająco sprawny w technologiach

22 informacyjnych

23 KC Potrafię swobodnie wykorzystywać najpopularniejsze narzędzia cyfrowe (tj. PC, smartfon, laptop, tablet, etc.)

24 KK Potrafię pracować w grupie

25R KK Uważam, że z trudem nawiązuję relacje z innymi ludźmi

26R KP Bywam trudny w relacjach z innymi ludźmi

27R ONiK Nie da się połączyć się polityki integracji unii europej-

skiej z kulturową odrębnością

28 KSiO Angażuję̨ się w ważne dla mnie sprawy społeczne

29 KSiO Mam poczucie wpływu na to co mnie otacza

30 KK Potrafię motywować inne osoby do realizacji wspólnych

30 celów

31 KK Jestem skuteczny w negocjacjach

32R ONiK Świat nie oferuje zbyt wielu możliwości realizacji własnych pomystów

33R KP Nie lubię etapu planowania

1 = zdecydowanie się nie zgadzam, 5 = zdecydowanie się zgadzam

34R KP Uważam, że zazwyczaj kontrola i monitoring pracy są

bezcelowe

35R KP Zdarza mi się mieć poczucie własnej niegospodarności

podczas realizacji zadań

KK Rzadko udzielam informacji zwrotnych swoim współpracownikom

37 WJiWK Interesuję się różnymi kulturami

38R ONiK Nie ma takiej dziedziny sztuki, w której mógłbym

dobrze wyrazić siebie

39R ONiK Kultura wspófczesna jest dla mnie bezwartościowa

KK Kompetencje komunikacyjne (max. 60 pts.): 1, 2, 4R, 5, 6, 7, 8 , $24,25 \mathrm{R}, 30,31,36 \mathrm{R}$

WJiWK Wielojęzyczność i wielokulturowość (max. 25 pts.): 9, 11, 12,13,37

KC Kompetencje cyfrowe (max. 20 pts.): 20, 21, 22, 23

KP Kompetencje w zakresie przedsiębiorczości (max. 35 pts.): 16, 17R, 19, 26R, 33R, 34R, 35R

ONiK Otwartość na naukę i kulturę (max. 35 pts.): 10R, 14R, 15R, 27R, 32R, 38R, 39R

KSiO Kompetencje społeczne i obywatelskie (max. 20 pts.): 3, 18, 28, 29

R Odwrócona punktacja
INTERPRETACJA WYNIKÓW

Obecnie są prowadzone badania normalizacyjne na grupie reprezentującej populację edukatorów pochodzących z różnych krajów Europy. Na tym etapie autorzy proponuja tymczasowe normy przeliczania wyników ty punktów zyskanych w poszczególnych obszarach wyniki można przyporządkować do trzech grup: wyniki wysokie, średnie i niskie. Niskie wyniki świadczą o niskich kompetencjach edukatora w danym obszarze, a w zwiazzku z tym o wysokiej potrzebie doskonalenia tej kompetencji.

Interpretacja wyników

niskie średnie wysokie

\begin{tabular}{llll} 
KK & $12-13$ & $32-41$ & $42-60$ \\
\hline WJiWK & $5-13$ & $14-17$ & $18-25$ \\
\hline KC & $4-10$ & $11-14$ & $15-20$ \\
\hline KP & $7-18$ & $19-24$ & $25-35$ \\
\hline ONiK & $7-18$ & $19-24$ & $25-35$ \\
\hline KSiO & $4-10$ & $11-14$ & $15-20$
\end{tabular}


Poniżej znajduje się lista 18 twierdzeń odnosząca się do Twojej opinii na temat Twojego miejsca pracy. Zaznacz proszę na skali od

(zdecydowanie się nie zgadzam) do 5 (zdecydowanie się zgadzam), jak bardzo zgadzasz się z niżej wypisanymi zdaniami.

\section{Prosze o odpowiedź na KAŻDE zadane pytanie.}

1 = zdecydowanie się nie zgadzam, 5 = zdecydowanie się zgadzam
1

40 Czuję się doceniony przez pracodawce

41 Czuję się doceniony przez swojego bezpośredniego przełożo-

nego (np. kierownika, lidera, etc.)

42 W pehni realizuję cele stawiane przez pracodawcę

43 Moje miejsce pracy pozwala mi osiągać sukcesy zawodowe

Czuje odpowiedzialność za swoje stanowisko pracy i za zlecone mi zadania

Czuje się niezależnie podczas wykonywania zleconych mi zadań

Pracodawca umożliwia mi zdobywanie kolejnych szczebli zawodowych, awansowanie

47 Obecna praca wpływa na mój rozwój osobisty (poszerzanie wiedzy, uczenie się czegoś nowego)

48 Mój pracodawca ma sprecyzowany kierunek rozwoju orga-

49 Mój pracodawca nie spoczywa na laurach i ciągle rozwija organizację

$50 \quad$ Moje stanowisko pracy jest dostosowane do moich obowiązków

51 Czuję się komfortowo w wykonywaniu swoich obowiązków w pracy

52 Zarabiam godziwe pieniądze w mojej organizacji

3 Organizacja oferuje mi atrakcyjne dodatki i premie do

53 wynagrodzenia

54 Moje bezpośrednie relacje z przełożonym są satysfakcjonujące 


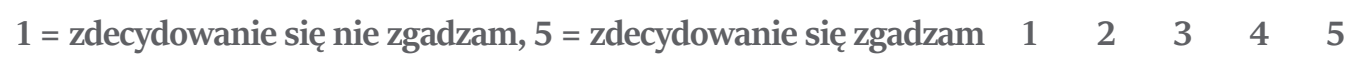

Moje bezpośrednie relacje z kolegami na tym samym stanowisku są satysfakcjonujące

56 Moja organizacja gwarantuje mi bezpieczeństwo zatrudnienia

57 Praca ma niekorzystny wpływ na moje życie prywatne

Zaznacz/wpisz właściwie

58. Płeć $\square \mathrm{M} \quad \square \mathrm{K}$

59. Wiek ...........

60. Typ organizacji

$\square$ Państwowa

$\square$ Prywatna

$\square$ NGO (np. stowarzyszenie, fundacja)

61. Zajmowane stanowisko (zaznacz X-em tylko JEDNO):

właściciel/dyrektor organizacji

manager średniego szczebla

seregowe

wolontariusz

\section{INTERPRETACJA WYNIKÓW}

Punktacja jest wyrażona procentowo. Każde zdanie ma minimalną wartość $0 \%$, a maksimum $100 \%$. Im wyższy wynik uzyska dana osoba, tym lepsza jest jej opinia o danym wymiarze funkcjonowania instytucji. Jedyny wyjątek stanowi ostatnia kategoria, która jest woncentrowana ma życiu prywatnym/oso. bistym. W tym obszarze niski wynik świadczy o odpowiednio niskim wpływie życia zawodowego na prywatne.

Zaleca się interpretację uzyskanych wyników odnośnie do oceny organizacji według poniższej skali:

0-20\% - bardzo niski- bardzo zła opinia na temat organizacji/pracodawcy

21-40\% - niski - zła opinia na temat organizacji/pracodawcy

41-60\% - średni - neutralne podejście do organizacji/pracodawcy

61-80\% - wysoki - dobra opinia na temat organizacji/pracodawcy

81-100\% - bardzo wysoki- bardzo dobra opinia na temat organizacji/pracodawcy $\frac{5}{8}-1=$

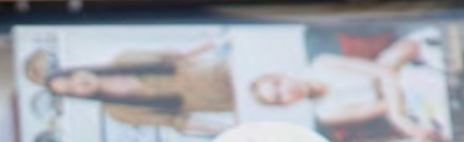

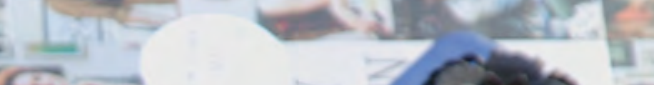
En w ros

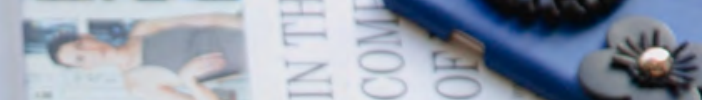

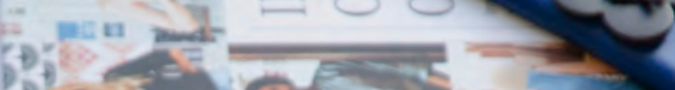

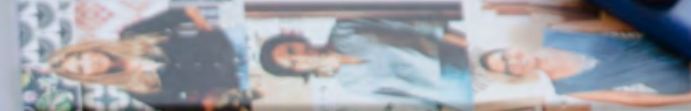

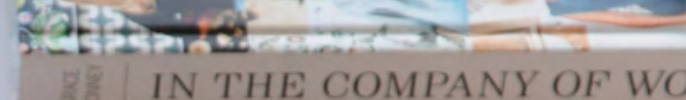
BE IN THE COMPANY OF WO
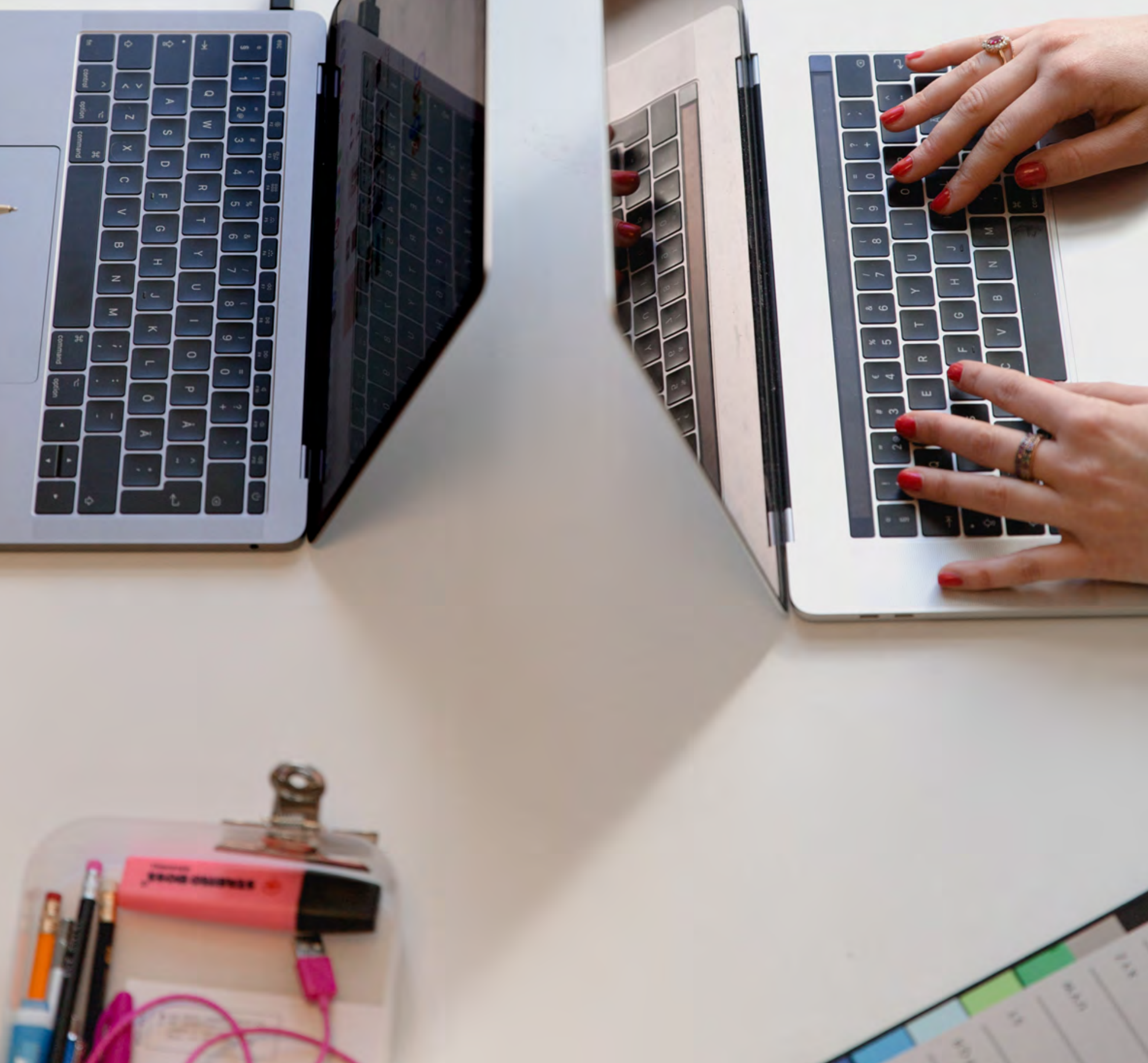

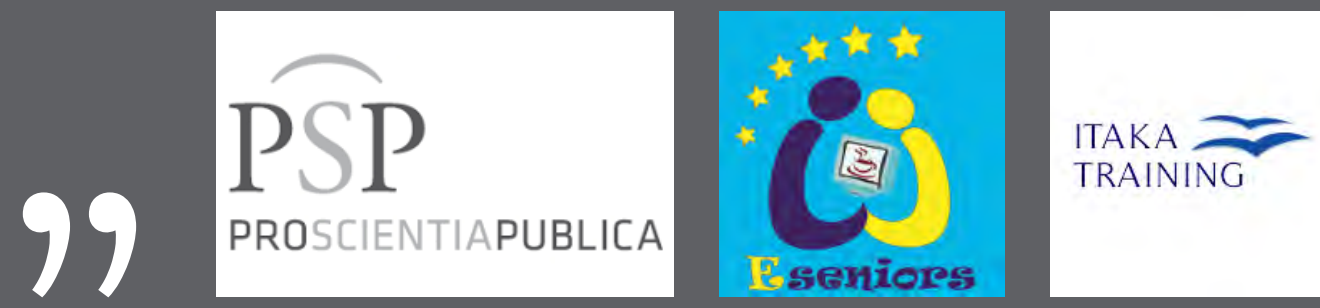

ISBN 978-83-953451-5-9 